DOI: $10.19195 / 0137-1134.116 .3$

RAJNHARDT KOKOT

ORCID: 0000-0002-6240-7282

Uniwersytet Wrocławski

\title{
SZCZEGÓLNA ODPOWIEDZIALNOŚĆ KARNA ZA PRZESTĘPSTWO CIĄGŁE W ŚWIETLE PROPOZYCJI ZMIAN DOTYCZĄCYCH USTAWOWEGO I SĄDOWEGO WYMIARU KARY W PROJEKCIE NOWELIZACJI KODEKSU KARNEGO Z 25 STYCZNIA 2019 ROKU
}

\begin{abstract}
Abstrakt: Opracowanie zawiera analizę oraz ocenę niektórych rozwiązań prawnych zaproponowanych w projekcie nowelizacji prawa karnego z 25 stycznia 2019 roku, w tym zwłaszcza dotyczących wymiaru kary, zarówno ustawowego, jak i sądowego. Zwrócono uwagę na zmiany stanowiące najbardziej jaskrawe przejawy wyraźnie zarysowanej w projekcie tendencji — wyrażonej zresztą wprost $\mathrm{w}$ założeniach postulowanych zmian — w kierunku zwiększenia represyjności unormowań kodeksu karnego z 1997 roku. Ta realizowana jest na trzech głównych płaszczyznach: 1. zwiększenia surowości sankcji za poszczególne, wyselekcjonowane typy przestępstw, 2. rozszerzenia stosowania instytucji nadzwyczajnego obostrzenia kary oraz 3. zmian dotyczących dyrektyw sądowego wymiaru kary. Opracowanie koncentruje się na zmianach dotyczących podstaw i reguł nadzwyczajnej progresji karania, zwłaszcza zaś na modyfikacji odnoszącej się do odpowiedzialności karnej za przestępstwo popełnione w warunkach czynu ciągłego objętego formułą art. $12 \S 1$ k.k. Projekt przewiduje $\mathrm{w}$ takim przypadku obligatoryjne obostrzenie kary poprzez podniesienie dolnego progu odpowiedzialności o połowę, górnego natomiast dwukrotnie. W tym zakresie przedstawione zostały zarówno argumenty stanowiska aprobującego takie rozwiązanie, jak i poglądy tej części doktryny prawa karnego, która w pełni akceptuje przyjęty w kodeksie karnym z 1997 roku i obowiązujący w tym zakresie stan prawny.
\end{abstract}

Słowa kluczowe: nowelizacja, represyjność, wymiar kary, obostrzenie kary, czyn ciągły, przestępstwo ciągłe, nadzwyczajny wymiar kary

I

Zasadniczym założeniem zmian zawartych w projekcie nowelizacji kodeksu karnego z 2019 roku$^{1}$, co wprost deklarowane jest przez jego autorów w Uzasad-

1 Projekt ustawy o zmianie ustawy Kodeks karny oraz niektórych innych ustaw z dnia 25 stycznia 2019 roku, https://legislacja.rcl.gov.pl (dostęp: 14.11.2019). 
nieniu nowych propozycji, jest radykalne zwiększenie represyjności obowiązującego prawa karnego. Można więc przyjąć — odwołując się do starego porzekadła charakteryzującego na znacznie ogólniejszym poziomie niż jedynie przestrzeń polityki karnej elementarne metody stymulacji pożądanych postaw ludzkich, a które w tym przypadku narzuca się w sposób nieodparty — iż w projekcie istotnie wzmocniona została „strategia kija”, wyrażająca się w stosowaniu groźby surowej i bardzo surowej odpowiedzialności karnej, z jednoczesnym zauważalnym osłabieniem „strategii marchewki”, a więc tych rozwiązań, które na płaszczyźnie subtelniejszej niż surowa dolegliwość karna mają kształtować właściwe, oczekiwane przez ustawodawcę, zachowania i postawy adresatów jego działań. Jak w Uzasadnieniu projektu argumentują jego autorzy, zasadniczym jego założeniem „była potrzeba wzmocnienia ochrony prawnokarnej w zakresie czynów godzących w tak fundamentalne dobra prawne jak życie i zdrowie ludzkie, wolność seksualna czy własność" 2 . Niezbędna do jej realizacji ma być na nowo ukształtowana formuła sankcji karnych o zwiększonej represyjności grożących za przestępstwa skierowane przeciwko tym dobrom - zresztą, jak wynika z propozycji zmian w zakresie części szczególnej, nie tylko tym — na które zamachy „budzą silną społeczną potrzebę odpłaty i napiętnowania" ${ }^{3}$. Potrzeba zmian w tym kierunku jest przy tym wyprowadzana wprost z ustawy zasadniczej, ściślej z art. 31 ust. 3 Konstytucji RP z 1997 roku, który, według argumentacji autorów projektu, odwołuje się do „pozytywnej funkcji sprawiedliwościowej teorii proporcjonalności”, zawierając „nakaz zapewnienia dostatecznej ochrony dóbr konstytucyjnych, zarówno o charakterze indywidualnym, jak i kolektywnym", której zaniechanie należałoby traktować jako

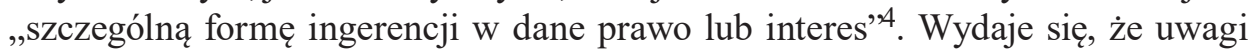
wprowadzające do Uzasadnienia postulowanych zmian w prawie karnym mogą w tym zakresie ich motywowania budzić spore wątpliwości. Jak dalej wskazuje się w Uzasadnieniu, projektowane zwiększenie stopnia punitywności rozwiązań prawnych realizowane jest na trzech płaszczyznach. Po pierwsze, jak już wspomniano, wyraża się ono w zwiększonej surowości sankcji przewidzianej za określone typy przestępstw, po drugie, w rozszerzeniu stosowania instytucji nadzwyczajnego obostrzenia kary, wreszcie „obostrzenie trzeciego stopnia” tworzą zmiany dotyczące ogólnych dyrektyw wymiaru kary ukierunkowane „w stronę wyboru bardziej surowej sankcji" . Ponadto, jak wskazuje się w Uzasadnieniu projektu, nowelizacja ma też za zadanie — co można odebrać jako rodzaj jej „,wartości dodanej” — usunięcie lub zmianę dotychczasowych nieracjonalnych i nieefektywnych unormowań, dotkniętych „wadami merytorycznymi”, a także „wyeliminowanie niespójności i luk prawnych", które ujawniły się w toku stosowania obowiązującego stanu prawnego ${ }^{6}$.

\footnotetext{
${ }^{2}$ Uzasadnienie Projektu z 25 stycznia 2019 roku, s. 1.

3 Ibidem.

4 Ibidem.

5 Ibidem, s. 2.

${ }^{6}$ Ibidem.
} 
Chcąc choć w ogólnym zarysie — opracowanie niniejsze koncentruje się bowiem na jednej tylko spośród zaproponowanych zmian — przedstawić kierunki sugerowanych rozwiązań, należy wskazać niektóre „kamienie milowe” nowego ujęcia prawa karnego, zwłaszcza w zakresie części ogólnej kodeksu karnego, charakteryzując je w dużym uproszczeniu i na takim też poziomie oceniając ich zasadność, nie wiążąc się przy tym ani chronologią układu znowelizowanych przepisów, ani też trudnym $w$ praktyce w użyciu kryterium rangi i znaczenia poszczególnych projektowanych rozwiązań. Niewątpliwie wśród proponowanych zmian szczególnie zauważalne są te, które dotyczą systemu szeroko rozumianych środków prawnokarnej reakcji, w tym zwłaszcza kar, szczególnie zaś tych najsurowszych. $\mathrm{W}$ tym zakresie projekt rezygnuje $\mathrm{z}$ obecnej w systemie polskiego prawa karnego od niemal pół wieku punktowej kary pozbawienia wolności 25 lat jako niedającej „możliwości miarkowania kwantum prawnokarnej dolegliwości”, „płynnej” reakcji na konkretne przestępstwo, co w wielu przypadkach w praktyce może prowadzić do wymiaru „kary nieadekwatnej, czyli zbyt łagodnej lub zbyt surowej”, co sprzeczne jest z zasadą indywidualizacji odpowiedzialności karnej ${ }^{7}$. Ten interwałowy system kar izolacyjnych, który w praktyce wymiaru sprawiedliwości — jak ocenia projektodawca - się nie sprawdza, ma zastąpić podział kary pozbawienia wolności na karę terminową od jednego miesiąca do lat 30 (art. 37 projektu) ${ }^{8}$, przy jednoczesnym utrzymaniu kary dożywotniego pozbawienia wolności, w tym także w formie kary „bezwzględnie dożywotniej” — stosowanej obligatoryjnie lub fakultatywnie - a więc bez możliwości zastosowania warunkowego przedterminowego zwolnienia, stanowiącej realną, a nie tylko nominalną alternatywę dla usuniętej z kodeksu karnego z 1997 roku eliminacyjnej kary głównej (art. 77 § 3 i $\S 4$ projektu) ${ }^{9}$. Co do tego ostatniego rozwiązania wydaje się, że wobec licznych wypowiedzi piśmiennictwa na temat takiego ujęcia kary dożywotniego pozbawienia wolności, jako realnej alternatywy dla kary śmierci, formułowanych w ciągu ostatnich kilku dekad w kontekście poszukiwań skutecznego środka zastępczego dla tej kary, szersze argumentowanie nietrafności tego rozwiązania jest zbędne. Należy jedynie przywołać argumenty w tym zakresie „koronne”. Z jednej strony kwestionować bowiem można samą zgodność tego rozwiązania z unormowaniami

7 Ibidem.

8 Jak argumentuje projektodawca, rozwiązanie to uzasadnia fakt, że kodeks operuje „szeroko opisanymi, zgeneralizowanymi typami przestępstw”, co sprawia, iż dla „zapewnienia swobody orzeczniczej sądu i umożliwienia wymierzenia w pełni zindywidualizowanej kary" pożądane jest rozszerzenie możliwej prawnokarnej reakcji na czyn zabroniony. Należy dodać, że pułap 30 lat byłby jednocześnie górną granicą kary pozbawienia wolności wymierzanej w warunkach nadzwyczajnego obostrzenia (art. $38 \S 2$ projektu). Ibidem, s. 2-3.

9 Wyrazem zwiększonej w tym zakresie represyjności proponowanych rozwiązań prawnych jest też przewidziana $\mathrm{w}$ art. $78 \S 3$ projektu możliwość stosowania w przypadku wymierzenia dożywotniego pozbawienia wolności - nieobjętego regulacją art. 77 § 3-4 projektu — warunkowego przedterminowego zwolnienia dopiero po 35 latach kary odbytej, którego okres próby „trwa dożywotnio" (art. $80 \S 3$ projektu). 
konstytucyjnymi oraz wspólnotowymi ${ }^{10}$, z drugiej zwrócić uwagę, że tak ujęta kara dożywotniego pozbawienia wolności stanie się środkiem stricte eliminującym, ochronnym, pozbawionym możliwości realizacji innych funkcji kary, a skazanie na nią uczyni sprawcę na etapie jej wykonywania de facto bezkarnym, stawiając go ponad wszelkimi normami obowiązującego systemu prawnego.

Ekstremalnym wyrazem nurtu „usurowienia” odpowiedzialności karnej są też nowe zasady stosowania unormowań kodeksowych wobec sprawców nieletnich, którzy dopuścili się czynu zabronionego po ukończeniu 15 roku życia, a przed ukończeniem lat 17. Dotychczasowa formuła ich wyjątkowej odpowiedzialności karnej ,jak dorośli”, obejmująca stosunkowo nieliczne, najcięższe, wymienione enumeratywnie zbrodnie oraz najcięższe występki, zastąpiona została szeroką klauzulą odpowiedzialności za każdą zbrodnię oraz bardzo licznie wymienione w tym przepisie występki (art. $10 \S 2$ projektu). Ponadto projekt usunął dotychczasowe ograniczenie wymiaru kary do dwóch trzecich ustawowego zagrożenia, otwierając sądowi drogę do wymierzenia kary w pełnych ramach sankcji, a więc do jej górnego pułapu (art. $10 \S 3$ projektu) ${ }^{11}$. Zachowane natomiast zostało przewidziane w tym przepisie dobrodziejstwo, na które w dotychczasowym ujęciu mogli liczyć nieletni sprawcy w postaci fakultatywnego nadzwyczajnego złagodzenia kary. Nie zmieniły się też ustawowe obwarowania wyjątkowej, karnej odpowiedzialności nieletnich dotyczące okoliczności sprawy, ich stopnia rozwoju oraz warunków i właściwości, a także skuteczności wcześniej stosowanych wobec nich środków wychowawczych lub poprawczych (art. $10 \S 2$ projektu).

Wśród zmian niewątpliwie wyrażających przyjęty w projekcie ogólny kierunek trzeba wskazać także niezmiernie uszczegółowione, „kazuistyczne” zasady stosowania kary grzywny oraz kary ograniczenia wolności, ograniczające działanie zasady swobodnego uznania i narzucające sądowi określone minima ich wymiaru, $\mathrm{w}$ zależności od przewidzianych $\mathrm{w}$ danym przepisie granic zagrożenia

10 W szczególności w grę wchodzi naruszenie art. 41 ust. 4 Konstytucji Rzeczypospolitej Polskiej (Konstytucja Rzeczypospolitej Polskiej z dnia 2 kwietnia 1997 roku, Dz.U. Nr 78, poz. 483 ze zm.) oraz art. 3 Konwencji o ochronie praw człowieka i podstawowych wolności, sporządzonej w Rzymie dnia 4 listopada 1950 roku (Dz.U. z 1993 r. Nr 61, poz. 284 ze zm.), z których wynika nakaz traktowania w sposób humanitarny każdego pozbawionego wolności oraz zakaz tortur i nieludzkiego lub poniżającego traktowania albo karania. Proponowane rozwiązania mogą też naruszać art. 10 oraz art. 175 ust. 1 Konstytucji RP z 1997 roku.

11 Por. Uzasadnienie projektu z 25 stycznia 2019 roku, s. 7-8. W uzasadnieniu zmianę tę argumentowano tym, że „sąd orzekający powinien mieć możliwość orzekania kary w bardzo szerokich granicach, adekwatnych do konkretnego wypadku". Wydaje się, że zwłaszcza wobec modyfikacji ogólnych granic wymiaru kary pozbawienia wolności poprzez podniesienie jej górnego progu, trudno uznać, by nawet w najcięższych przypadkach przestępstw popełnionych przez sprawców między 15 a 17 rokiem życia wymiar 30 lat kary pozbawienia wolności — kara dożywotniego jej wymiaru jest bowiem z mocy art. $54 \S 2$ niezmiennie wyłączona - można było traktować jako „adekwatny” wobec czynu i winy tak młodego sprawcy. Jednocześnie trzeba przyznać, że przepis art. $10 \S 2$ wymagałby pewnej korekty w zakresie katalogu czynów objętych jego regulacją, choć nie w tak szerokim zakresie, jak uczyniono to w projekcie. 
karą pozbawienia wolności (art. $33 \S 1$ a oraz art. $34 \S 1$ 1a) ${ }^{12}$. Należy wymienić także istotne przemodelowanie art. 37a kodeksu. Wobec bogactwa zmian, a także wyłączeń, jakie zaproponowano w jego konstrukcji, wypada wręcz chyba uznać go za rozwiązanie zupełnie nowe, trudno bowiem dostrzec w nim kontynuację realizacji dotychczasowej funkcji przypisanej temu unormowaniu. Trzeba wszakże przyznać, że akurat obniżenie progu stosowania dobrodziejstw tego przepisu z 8 do 5 lat zagrożenia karą pozbawienia wolności, wydaje się nie tyle posunięciem zwiększającym surowość reakcji karnej, ile raczej racjonalizującym tę reakcję, wyraźnie, a nawet przesadnie zliberalizowaną mocą reformy z 20 lutego 2015 roku $^{13}$. Trudno bowiem uznać możliwość sądowego wymiaru kary za niektóre cięższe przestępstwa w ustawowych granicach od 100 zł grzywny do 8 lat pozbawienia wolności za właściwie realizujące funkcje prawa karnego, choćby z perspektywy gwarancyjnego wymogu reguły względnej określoności sankcji karnej. W takim przypadku zakres ,rozwarcia sankcji” trudny jest do zaakceptowania. Wreszcie do zmian, które także wpisują się w program zwiększenia represyjności prawa karnego należy zaliczyć nowe zasady wymiaru kary łącznej, zwłaszcza zaś te, które wynikają z arytmetyki jej stosowania zawartej w art. $86 \S$ 1a projektu.

Zmianą o „przełomowym” wymiarze — choć, jak się wydaje, raczej neutralną z perspektywy założenia, przyświecającego autorom nowelizacji, zwiększenia represyjności prawa karnego - jest dodanie do art. 53 trzech nowych paragrafów $\S 2 \mathrm{a}, \S 2 \mathrm{~b}$ oraz $\S 2 \mathrm{c}$ - wprowadzających nieznany dotąd polskiemu powszechnemu prawu karnemu materialnemu szczegółowy katalog okoliczności obciążających oraz łagodzących uwzględnianych przy wymiarze kary. Projektodawca zaproponował zatem sądom orzekającym w sprawach karnych tę samą drogę indywidualizacji i konkretyzacji wymiaru kary, jaką dotąd zmierzały sądy i inne „organy orzekające" w sprawach o wykroczenia (art. 33 § 3 i 4 k.w.). Szczegółowe okoliczności wpływające na wymiar kary określone w art. 53 § 2 i $\S 3$, mające w zasadzie ambiwalentny charakter, których wartościowanie i ocena następują dopiero in concreto, uzupełnione więc zostały o „uszczegółowione”, jednoznaczne w swym charakterze, wymowie i ocenie, ujęte „dosłownie” wskazówki, udzielane w pierwotnym modelu stosowania przepisów kodeksu wykroczeń „nieprofesjonalnym”, w sensie karnistycznego przygotowania, kolegiom do spraw wykroczeń, wprost wskazujące sądowi, czym ma się kierować, jako okolicznościami obciążającymi lub łagodzącymi, w toku konkretyzacji i indywidualizacji kary. Uzasadnienie projektu zaproponowanych zmian wyraźnie tę zmianę bagatelizuje, komentując ją jednym zdaniem wskazującym, że katalogi te „nie mają charakteru zamkniętego”, tak jakby w praktyce mogło występować poważniejsze ryzyko interpretacji zawartej w tym przepisie, poprzedzającej wymienienie poszczególnych okoliczności,

\footnotetext{
12 Por. ibidem, s. 8-9.

13 Por. ibidem, s. 4 i 10-11.
} 
klauzuli „w szczególności”14. Ranga tej zmiany niewątpliwie wymagałaby od jej autorów gruntowniejszego odniesienia się do potrzeby jej wprowadzenia i jej szerszego uzasadnienia. Rozwiązanie to należy uznać za wysoce niefortunne. Trudno bowiem założyć, że ułatwi ono, usprawni czy uwiarygodni proces sądowego wymiaru kary i zobiektywizuje dolegliwość kary wymierzonej w konkretnym przypadku. Oceniając je, należy stwierdzić, że wyraża ono raczej brak wiary i zaufania do profesjonalnego organu stosującego normy prawa karnego, stanowiąc widoczny rodzaj ,pouczania o sprawach oczywistych”, o tyle chybionego, że skierowanego do wysoce profesjonalnego, merytorycznie przygotowanego, wyspecjalizowanego w zakresie stosowania norm prawa karnego, w tym przepisów dotyczących wymiaru kary, grona adresatów. Należy przy tym zwrócić uwagę, że zestawy te, jak też poszczególne okoliczności wymienione w tych przepisach, dotknięte są wadą wynikającą z nadmiernej ich kazuistyki, jednocześnie zaś wykazują bardzo wysoki poziom niedookreśloności i ocenności. Niektóre z nich wprost odwołują się do pojęć nieużywanych już w ustawie karnej, zastąpionych nie tylko przez ich nowe brzmienia, ale i nowe znaczenia (na przykład art. $53 \S 2 \mathrm{a}$ pkt 6). Niewątpliwie zmiana ta wymagałaby szerszego omówienia, jej waga i skutki są bowiem ogromne i w rzeczy samej trudne do przewidzenia. Ramy niniejszego opracowania i jego merytoryczny profil na to jednak nie pozwalają. W kontekście zmian w art. 53 k.k. wypada jedynie wspomnieć — kwestia ta także wymagałaby bowiem znacznie gruntowniejszej analizy — że projekt rezygnuje z wąskiego, mającego kształtować jedynie „świadomość prawną społeczeństwa”, ujęcia dyrektywy prewencji generalnej, uznając tę regulację za „przejaw czysto idealistycznej aksjologii"15. Powrót do szerokiego jej ujęcia, obejmującego także jej aspekt „negatywny” realizujący funkcję „odstraszania” społeczeństwa od popełniania przestępstw karą — nie tylko grożącą w ustawie, co przyświeca przecież przeważającej części zaproponowanych w projekcie zmian, lecz także wymierzaną in concreto przez sąd - należy uznać za niewłaściwe, a wiarę w skuteczność tego kierunku indywidualizacji kary zwłaszcza w kontekście niezmiennie obowiązującej w tym przepisie, limitującej wymiar kary, dyrektywy stopnia winy — za opartą na wąttych podstawach. Wyniki badań kryminologicznych dawno już i wielokrotnie wykazywały, że strach przed wymierzeniem kary surowej nie jest efektywnym czynnikiem powstrzymującym potencjalnego sprawcę przed popełnieniem przestępstwa.

W wąski kontekst głównego wątku niniejszej wypowiedzi wpisuje się niewątpliwie zmiana dotycząca szczególnych zasad odpowiedzialności sprawców

14 Ibidem, s. 13.

15 Ibidem, s. 6. 
wielokrotnie powracających do przestępstwa, a za jej sprawą — w związku z klauzulą odsyłającą wynikającą z art. 65 § 1 - także do innych kategorii sprawców szczególnie niebezpiecznych — popełniających przestępstwa w zorganizowanej grupie lub związku przestępczym, czyniących sobie z popełnienia przestępstwa stałe źródło dochodu, wreszcie dopuszczających się przestępstw o charakterze terrorystycznym. Jak wynika z zaproponowanego nowego ujęcia formuły nadzwyczajnej progresji karania multirecydywistów — sama bowiem konstrukcja tej odmiany recydywy specjalnej się nie zmieniła — sąd zobowiązany jest do wymierzenia kary pozbawienia wolności od podwójnej wysokości dolnego ustawowego zagrożenia do jego górnej granicy zwiększonej o połowę (art. $64 \S 2$ projektu) ${ }^{16}$. $\mathrm{O}$ ile więc nic nie zmienia się w zakresie modyfikacji górnego progu odpowiedzialności karnej tudzież obligatoryjnego wymogu stosowania kary izolacyjnej, także wówczas, gdy zwyczajny ustawowy wymiar kary przewiduje oprócz kary pozbawienia wolności również kary wolnościowe — z wyjątkiem, rzecz jasna, przypadków objętych regulacją art. 57 § 2 k.k. — o tyle zupełnie inaczej, choć trudno powiedzieć, że oryginalnie, przedstawia się, znacznie surowsza od obowiązującej, reguła nadzwyczajnego obostrzenia dolnego progu odpowiedzialności wielokrotnego recydywisty, a tym samym pozostałych sprawców objętych regulacją art. $65 \S 1$. Ta nawiązuje bowiem wprost, a wręcz jest z nią identyczna, do zasady nadzwyczajnego obostrzenia kary przewidzianej wobec recydywistów w rozumieniu regulacji art. $60 \S 1$ kodeksu karnego z 1969 roku, normującej tak zwaną recydywę specjalną prostą, sprzed jego nowelizacji z 12 lipca 1995 roku $^{17}$. Jak powszechnie wiadomo, czas funkcjonowania rozwiązań dotyczących nadzwyczajnej odpowiedzialności sprawców powrotnych ,specjalnych” w kodeksie karnym z 1969 roku naznaczony był nieustającą krytyką doktryny, odnoszącą się do reguł tego obostrzenia, którym zarzucano „mechaniczny” charakter i wiążący sędziom ręce ,,automatyzm” nadzwyczajnego wymiaru kary, sprzeczny z ideą indywidualizacji i sprawiedliwości karania. To ostatecznie doprowadziło do liberalizujących czy raczej racjonalizujących zasady odpowiedzialności karnej sprawców powrotnych zmian, wyprzedzających o kilka lat wejście w życie nowej kodyfikacji karnej. Zmiany te w swej treści były identyczne z przewidzianymi w kolejnych

16 Jak wynika z Uzasadnienia projektu, zmiana ta motywowana jest potrzebami zarówno prewencji indywidualnej, ,wedle której w stosunku do tej kategorii sprawców jedynie intensywne oddziaływanie w warunkach penitencjarnych jest w stanie skutkować wzbudzeniem pożądanych postaw społecznych”, jak i prewencji generalnej, co z kolei polega na „unaocznieniu społeczeństwu nieopłacalności takich czynów oraz tego, że ich popełnienie będzie spotykało się z surową karą". Jak w sposób ,życzeniowy” komentuje, ocenia i prognozuje skutki tej zmiany projektodawca, pozwoli ona „na zrealizowanie zamierzonych celów w zakresie oddziaływania kary na tę kategorię sprawców, znacząco przyczyniając się do ograniczenia rozmiarów zjawiska recydywy wielokrotnej”. Ibidem, s. 16.

17 Ustawa z dnia 12 lipca 1995 roku o zmianie Kodeksu karnego, Kodeksu karnego wykonawczego oraz podwyższeniu dolnych i górnych granic grzywien i nawiązki w prawie karnym (Dz.U. 1995, Nr 95, poz. 475). 
wersjach jej projektów, w tym ostatecznie przyjętego przez ustawodawcę. Wobec zaproponowanej modyfikacji ponownie więc - warto bowiem przypomnieć, że próba rekonstrukcji ducha „starszego modelu” reakcji na recydywę specjalną była już i uprzednio bezskutecznie podejmowana we wcześniejszych projektach nowelizacji kodeksu karnego z 1997 roku — aktualizują się wszystkie dotychczasowe, krytyczne argumenty podnoszone w nauce prawa karnego na przestrzeni kilku dekad obowiązywania art. 60 kodeksu karnego z 1969 roku.

Przejawem zmian, choć już nie tak wyrazistym, w zakresie wzrostu represyjności podstaw — ale nie reguły — nadzwyczajnego obostrzenia kary, jest też propozycja uzupełnienia katalogu przyczyn nadzwyczajnego obostrzenia kary przewidzianych w art. $178 \S 1$ k.k. Obecnie okolicznością szczególnie negatywnie charakteryzującą postawę sprawcy wobec uprzednio popełnionego, jednego $\mathrm{z}$ wymienionych $\mathrm{w}$ tym przepisie przestępstw przeciwko bezpieczeństwu w komunikacji (art. 173, art. 174 i art. 177), jest jego ucieczka z miejsca zdarzenia. W zakresie reguły nadzwyczajnego wymiaru kary jest ona traktowana analogicznie jak „charakteryzujący” sprawcę w związku z czynem stan jego nietrzeźwości lub stan pod wpływem środka odurzającego. Analogię tę uzasadnia przy tym nie fakt nieudzielania pomocy poszkodowanym $\mathrm{w}$ zdarzeniu — za to bowiem sprawca powinien odpowiadać osobno w warunkach realnego zbiegu przestępstw - ale o uniemożliwienie diagnozy stanu sprawcy w chwili czynu. Jak wskazuje Uzasadnienie projektu, do zbiegnięcia z miejsca zdarzenia

podobna pod względem aksjologicznym sytuacja zachodzi wówczas, gdy sprawca, bezpośrednio po popełnieniu w stanie nietrzeźwości lub odurzenia przestępstwa określonego w art. 178 § 1 k.k. spożywa napój alkoholowy lub zażywa środek odurzający po to, aby wykazywać, że w czasie popełnienia przestępstwa był trzeźwy lub nie był odurzony ${ }^{18}$.

Takie założenie uzasadniało zmianę polegającą na dodaniu do tego przepisu kolejnej podstawy nadzwyczajnego obostrzenia wynikającej z zachowania sprawcy polegającego właśnie na spożywaniu alkoholu lub zażywaniu środka odurzającego po zdarzeniu, a przed poddaniem się badaniu mającego na celu ustalenie stanu sprawcy w chwili popełnienia przestępstwa ${ }^{19}$. Takie zachowanie zostało objęte zatem domniemaniem, wpływającym na ocenę naganności postawy sprawcy, że tą drogą chciał ukryć rzeczywisty stan rzeczy, ściślej zaś stan nietrzeźwości lub stan pod wpływem środka odurzającego, w którym się znajdował. Jest więc ono traktowane jako swoisty „,substytut” zbiegnięcia z miejsca zdarzenia, które również uniemożliwia bądź co najmniej poważnie utrudnia ocenę stanu sprawcy tempore

18 Uzasadnienie Projektu z 25 stycznia 2019 roku, s. 36.

19 Niejasne są jednak motywy — Uzasadnienie projektu milczy bowiem w tej kwestii dlaczego w nowej konstrukcji art. 178, oprócz pojęcia środka odurzającego, użyto także pojęcia środka działającego podobnie do alkoholu. W tle licznych wypowiedzi doktryny prawa karnego pojęć tych nie można bowiem utożsamiać. Wprowadzenie do art. 178 tego nowego określenia burzy dotychczasową, względną zresztą, pewność i stabilność znaczeniową użytych w nim terminów. 
criminis. Choć wynikające jedynie ze wspomnianego domniemania zachowanie takie na poziomie wymiaru kary będzie traktowane tak samo jak spowodowanie jednego z przestępstw wskazanych w tym przepisie w niewątpliwym pod względem dowodowym stanie nietrzeźwości lub odurzenia, względnie ucieczka z miejsca popełnienia jednego z tych przestępstw, poszerzając katalog podstaw nadzwyczajnego obostrzenia wynikających z art. $178 \S 1$ k.k.

Zmianą, na którą należy zwrócić szczególną uwagę — nie tylko ze względu na jej „nowość”, lecz także „,rewolucyjną” treść — jest ta, która wynika z art. 57b projektu. Jak stanowi ten przepis, ,skazując za przestępstwo określone w art. 12 $\S 1$ sąd wymierza karę przewidzianą za przypisane sprawcy przestępstwo w wysokości od dolnej granicy zagrożenia zwiększonego o połowę do podwójnej wysokości górnej granicy ustawowego zagrożenia”. Zaproponowana modyfikacja reguł odpowiedzialności za przestępstwo ciągłe zdaje się być wyrazem dalszego ciągu prac nowelizacyjnych nad udoskonaleniem tej konstrukcji normatywnej, zapoczątkowanych wraz z uzupełnieniem regulacji art. 12 o dodany do niego w 2018 roku paragraf drugi ${ }^{20}$, którego — jak się wydaje — podstawowym, a być może jedynym zadaniem, było usprawnienie praktyki wymiaru sprawiedliwości w tych wszystkich wątpliwych przypadkach, w których nie było możliwości procesowego dowiedzenia istnienia po stronie sprawcy dwóch lub więcej umyślnych wykroczeń przeciwko mieniu, podjętych przez sprawcę w krótkich odstępach czasu, ,z góry powziętego zamiaru" ich popełniania ${ }^{21}$.

20 Art. 3 ustawy z dnia 4 października 2018 roku o zmianie ustawy Kodeks wykroczeń oraz niektórych innych ustaw (Dz.U. 2018, poz. 2077).

21 Jedynie na marginesie wypada zauważyć, iż „kompleksowo ujęte” w art. $12 \S 2$ okoliczności, mające na płaszczyźnie dowodowej być rodzajem alternatywy dla zamiaru z góry powziętego, $\mathrm{z}$ innej zaś perspektywy, spoiwem łączącym poszczególne zachowania w toku procedury przypisania sprawcy jednego czynu, dotknięte są pewną legislacyjną niekonsekwencją. Wydaje się bowiem, że ustawodawca niepotrzebnie rozdrobnił przesłanki przypisania jednego czynu nawiązując przy charakterystyce kilku zachowań sprawcy składających się na jeden czyn do wykorzystania „tej samej albo takiej samej sposobności” bądź ich realizacji „,w podobny sposób” odchodząc od przyjętej w nowelizacji z 20 lutego 2015 roku formuły ciągu przestępstw z art. 91 $\S 1$, posługującej się znamieniem w postaci wykorzystania „takiej samej sposobności”. Z jednej strony w art. $12 \S 2$ k.k. użyta została bowiem przesłanka ciągu, z której ustawodawca, wraz ze wspomnianą reformą art. $91 \S 1$, zrezygnował — ,podobny sposób popełnienia” — z drugiej natomiast, jak się wydaje bez logicznego uzasadnienia, zastosowano w alternatywie przesłankę wykorzystania „tej samej” sposobności, która w sensie logicznym mieści się przecież w zakresie „takiej samej” sposobności. W kontekście brzmienia przepisu art. $91 \S 1$, przy posłużeniu się wnioskowaniem a maiori ad minus, niepodobna przecież nie przyjąć konstrukcji ciągu przestępstw w tych przypadkach, w których sprawca wykorzystał nie „taką samą”, lecz wprost „tę samą” sposobność. Odmienna wykładnia tej przesłanki byłaby sprzeczna z funkcją, jaką regulacja ta ma realizować, 
Kontynuacja normatywnych zmian w zakresie następstw przestępstwa ciągłego podjęta w projekcie z 2019 roku ma znacznie szerszy zakres niż przywołana uprzednio modyfikacja art. 12 k.k. i rodzi dalej idące konsekwencje prawne. Zwraca uwagę treść reguły nadzwyczajnego obostrzenia kary przewidzianego w dodanym przepisie art. 57b. To nowa jakość na tle dotychczasowych, znanych rodzimym kodyfikacjom prawa karnego powszechnego, formuł nadzwyczajnej progresji karania. Odbiega ona nie tylko od zasady obostrzenia kary wynikającej z art. 58 kodeksu karnego z 1969 roku wobec sprawcy wskazanego w tym przepisie „przestępstwa ciągłego", dającej możliwość wymierzenia kary do górnej granicy ustawowego zagrożenia podniesionej o połowę, czy analogicznych w zakresie reformy granic odpowiedzialności następstw ciągu przestępstw, określonych w art. $91 \S 1$ k.k., ale także od wszystkich pozostałych reguł nadzwyczajnego obostrzenia w obowiązującym kodeksie karnym. O ile jeszcze metoda przyjęta w art. 57b projektu dla modyfikacji dolnego progu ustawowych granic odpowiedzialności występuje i przy innych podstawach nadzwyczajnego obostrzenia kary (art. 57a $\S 1$ czy art. $178 \S 1$ k.k.), o tyle rozwiązaniem bezprecedensowym, jakościowym novum, jest ultrasurowy model podwyższenia górnego pułapu przewidzianej w ustawie odpowiedzialności karnej ${ }^{22}$. Nie wymaga wszakże szerszego dowodzenia to, że dwukrotne (a nie o połowę!) podniesienie górnego progu odpowiedzialności przewidzianego w sankcji prowadzi do możliwości wymierzania kar drakońsko surowych, co odczuwane będzie — rzecz jasna — tym bardziej, im wyższa będzie górna granica ustawowego zagrożenia przewidziana za dany typ przestępstwa. Wymowy tego argumentu nie może przy tym „rozmiękczać” ani teza, że o rzeczywistej surowości odpowiedzialności karnej decyduje w istocie rzeczy jej dolny, nie zaś górny próg, ani związana z tym założeniem, powszechnie znana i przywoływana w doktrynie, skłonność sądów do wymierzania kar oscylujących bliżej dolnych niż górnych progów odpowiedzialności karnej, niezależnie od tego, czy wynikają one z reguł zwyczajnego, czy nadzwyczajnego wymiaru kary.

Zmianę tę należy uznać za istotną z jednego jeszcze powodu. Wychodzi ona bowiem naprzeciw postulatom części doktryny prawa karnego formułowanym od początku obowiązywania kodeksu karnego z 1997 roku, a nawet jeszcze w toku prac nad kolejnymi wersjami projektów tej kodyfikacji. W kontekście spostrzeżenia dotyczącego rangi tej zmiany doprawdy trudno zrozumieć, dlaczego Uzasadnienie projektowanych zmian pomija je całkowitym milczeniem, choć — jak się wydaje - w tym akurat przypadku proponowanych rozwiązań warto było niżej

kłócąc się przy okazji z tak zwanym zdrowym rozsądkiem interpretatora tego przepisu. Rozbieżność w ujęciu tych przedmiotowych przesłanek stosowania obu instytucji, wywodzących się wszakże ze wspólnego pnia, może więc budzić uzasadnione opory.

22 Taki model nadzwyczajnego obostrzenia górnej granicy występuje natomiast w kodeksie karnym skarbowym z 10 września 1999 roku (Dz.U. 1999, Nr 83, poz. 930). Przewiduje go art. 38 $\S 2$ za czyny zabronione enumeratywnie wymienione w tym przepisie, gdy „kwota uszczuplonej należności publicznoprawnej lub wartość przedmiotu czynu zabronionego jest wielka". 
pochylić się nad kwestią argumentacji tej propozycji. To zaniechanie w pewnym sensie stało się bezpośrednią inspiracją do wyrażenia kilku uwag w tej kwestii niejako w zastępstwie autorów projektu — mających rekompensować, choć w części, niedostatki Uzasadnienia w zakresie motywacji tego rozwiązania.

Jak już wcześniej wspomniano, w nauce prawa karnego od dawna aktualne pozostawało pytanie, dlaczego instytucja czynu ciągłego w rozumieniu art. 12 k.k., wywodząca się wszakże z tej samej konstrukcji normatywnej — przestępstwa ciągłego w rozumieniu art. 58 k.k. z 1969 roku tworzącego wówczas jednolitą podstawę nadzwyczajnej progresji karania — nie spotyka się z analogicznymi skutkami w sferze wymiaru kary jak ciąg przestępstw. W piśmiennictwie, jeszcze przed wejściem w życie kodeksu karnego z 1997 roku, dał o sobie znać spór o zasadność tej dyferencjacji. Pogląd akceptujący rozwiązanie przyjęte w nowym kodeksie karnym uzasadniany był na kilka sposobów. Według pierwszego z nich odwoływano się do argumentu przytaczanego jeszcze pod rządami kodeksu karnego z 1969 roku, że niedopuszczalne jest dwukrotne zaliczanie tej samej okoliczności, jaką jest powtarzalność zachowania w ramach i warunkach jednego przestępstwa ciągłego, z jednej strony jako podstawy przejścia na typ kwalifikowany (na przykład w związku ze znaczną wartością zabranego mienia), a następnie dodatkowo jako podstawy nadzwyczajnego obostrzenia kary ${ }^{23}$. Motywacja taka aktualizowała się, rzecz jasna, na zasadzie analogii, także w przypadku sekwencji „zachowań” niestanowiących z osobna przestępstw, lecz jedynie wykroczenia lub czyny o znikomym stopniu społecznej szkodliwości. Także bowiem w tym przypadku uwzględnienie ciągłości jako podstawy przestępności wynikającej z sumowania oceny poszczególnych nieprzestępnych zachowań wraz z możliwością nadzwyczajnego obostrzenia kary za to „sumaryczne przestępstwo” byłoby dublowaniem tej samej okoliczności wpływającej na charakter i zakres odpowiedzialności karnej. W tym kontekście Marian Cieślak, kontestując co do zasady celowość nadzwyczajnego obostrzenia kary za przestępstwo ciągłe, formułował wprost wątpliwość, dlaczego „ten, kto wykonał zamierzony czyn ratami, ma być (a przynajmniej może być) ukarany z 50-procentową podwyżką kary w stosunku do sprawcy, który uczynił to za jednym zamachem" 24 .

Rezygnację z możliwości nadzwyczajnego obostrzenia kary wobec sprawcy czynu ciągłego uzasadniano także podobieństwem takiej sekwencji zachowań do kategorii tak zwanych przestępstw zbiorowych, których dyspozycja charakteryzowała w ustawowym opisie znamion typu czynność wykonawczą jako wielokrotną czy też powtarzalną. Uzasadniając stanowisko przyjęte w kodeksie w zakresie jedynie „Zwyczajnej” karalności przestępstwa ciągłego, wskazywano, że

23 Por. K. Buchała, Prawo karne materialne, Warszawa 1989, s. 430; I. Andrejew, Polskie prawo karne w zarysie, Warszawa 1976, s. 241; wyrok SN z 22 listopada 1975 roku, IV KR 215/75, OSNKW 1976, nr 2, poz. 26; wyrok SN z 12 marca 1975 roku, V KR 371/74, OSNPG 1975, nr 11, poz. 117; wyrok SN z 8 lipca 1977 roku, IV KR 125/77, OSNPG 1977, nr 11, poz. 100.

24 M. Cieślak, Polskie prawo karne. Zarys systemowego ujęcia, Warszawa 1994, s. 397. 
skoro w odniesieniu do sprawcy tych zachowań nie ma możliwości nadzwyczajnej progresji karania - wymiar kary następuje bowiem w granicach zwyczajnego wymiaru kary (ustawowego zagrożenia) określonego w sankcji przestępstw wieloczynnościowych - to i w odniesieniu do art. 12 k.k., na zasadzie analogii uzasadnione jest pominięcie możliwości nadzwyczajnego obostrzenia, brakuje bowiem powodów do różnicowania tych przypadków i surowszego traktowania sprawcy czynu ciągłego ${ }^{25}$.

Należy zwrócić wreszcie uwagę, że pogląd o potrzebie łagodniejszego traktowania sprawcy przestępstwa ciągłego, uderzający w przewidzianą w art. 58 k.k. z 1969 roku możliwość nadzwyczajnego obostrzenia kary — a mogący racjonalizować brak reguły nadzwyczajnego wymiaru kary w art. 12 k.k. — uzasadniany był w literaturze także szczególną treścią strony podmiotowej. Zdaniem Adama Sadowskiego argumentem za łagodniejszym traktowaniem sprawcy przestępstwa ciągłego miał być na tej płaszczyźnie niższy stopień winy sprawcy kilku pozostających w związku czynów. Skoro bowiem wynikały one z jednego impulsu woli „dokonanie jednego aktu w warunkach sprzyjających stępia niewątpliwie wrażliwość moralną przestępcy, zmniejsza stopień ujemnej oceny, przez co obniża natężenie jego winy"26.

Uznając racjonalność niektórych spośród przytoczonych powodów rezygnacji w kodeksie karnym z 1997 roku z możliwości nadzwyczajnego obostrzenia kary za czyn ciągły, nie można nie dostrzegać pewnych niekonsekwencji i mankamentów tego rozwiązania. Odnosząc się do pierwszego z argumentów zwolenników stanowiska przyjętego w kodeksie, trzeba przyznać, że wątpliwość ta jest w pełni zasadna w odniesieniu do tej części przypadków wielości zachowań tworzących przestępstwo ciągłe, w której czyny (zachowania) jednostkowe, brane pod uwagę każdy z osobna, nie realizują znamion typu czynu zabronionego, a dopiero zsumowanie ich następstw pozwala na przypisanie sprawcy przestępstwa, jak i wtedy gdy znamię ilościowe ujętych sumarycznie zachowań kreuje zagrożony surowszą karą typ kwalifikowany. Należy się jednak zgodzić z Krystyną Daszkiewicz, która kwestionując zasadę wymiaru kary za czyn ciągły, zwraca uwagę, że konstrukcja ta odnosi się nie tylko do „zachowań”, które oceniane z osobna nie są przestępstwami, stając się nimi dopiero wraz z całościową ich oceną, ale także „zachowań”, które — gdy oceniać je w oderwaniu od siebie — są takimi samymi przestępstwami jak te, które tworzą ciąg przestępstw. W przypadku wielości zachowań traktowanych sumarycznie nie zawsze ekwiwalentem nadzwyczajnego obostrzenia jest też przejście na typ kwalifikowany przewidujący surowszą odpowiedzialność

25 Por. M. Dąbrowska-Kardas, P. Kardas, Czyn ciagły i ciag przestępstw w kodeksie karnym z 1997 r., [w:] Nowa kodyfikacja karna. Kodeks karny. Krótkie komentarze, Warszawa 1998, s. 79.

26 A. Sadowski, Przestęstwo ciagte, Lublin 1949, s. 37, cyt. za: W. Zalewski, Przestępstwo ciagte de lege lata $i$ de lege ferenda, Prok. i Pr. 2003, nr 4, s. 78. 
karną ${ }^{27}$. Jeżeli więc w skład przestępstwa ciągłego wchodzą „,zachowania”, które - każde z osobna — realizują znamiona określonego typu czynu zabronionego, a ich multiplikacja nie prowadzi do surowszej odpowiedzialności w ramach typu kwalifikowanego, a więc gdy określony typ przestępstwa nie przewiduje cięższej odmiany stypizowanej na podstawie znamienia ilościowego - a takie przypadki są przecież absolutną większością w ustawie karnej - możliwość wymierzenia sprawcy kary za wielość zachowań (czynów) tworzących przestępstwo ciągłe w takich samych granicach jak w razie dopuszczenia się jednego tylko czynu może rodzić nieodparte wrażenie bezkarności niektórych, a nawet większości z nich, tym większe, im więcej czynów jednostkowych w warunkach zamiaru z góry powziętego sprawca się dopuścił ${ }^{28}$. W tej sytuacji nie tylko względy kryminalnopolityczne, ale także powinność uwzględnienia przy wymiarze kary ogólnych dyrektyw, zwłaszcza zaś dyrektywy sprawiedliwościowej, wskazywałaby na potrzebę dania sądowi choćby możliwości uadekwatnienia dolegliwości karnej, gdy górna granica zagrożenia karą przewidziana za przestępstwo, którego znamiona sprawca wielokrotnie wyczerpał, okaże się z tej perspektywy niewystarczająca. Tak ujęte zarzuty wspiera dodatkowo argument, że w ramach czynu ciągłego mogą być realizowane także bardzo poważne przestępstwa, w tym zbrodnie. Traktowanie wielości zbrodni, gdy wynikają one z tożsamego zamiaru, jako „zbrodni ciągłej”, na którą jedyną reakcją jest jedna kara mieszcząca się w granicach jej zwyczajnego wymiaru, z perspektywy realizacji dyrektywy sprawiedliwościowej musi budzić uzasadnione zastrzeżenia. Wymóg tożsamości osoby pokrzywdzonego w przypadku zamachów na dobra osobiste w pewnym stopniu te obawy redukuje, inna ich część pozostaje jednak niezmiennie aktualna ${ }^{29}$. Brak możliwości

27 K. Daszkiewicz, Kary za przestępstwa ciagłe i ciagi przestępstw, Prok. i Pr. 2000, nr 5, s. 23-24.

28 Por. ibidem; K. Daszkiewicz, Nadzwyczajne obostrzenie kary, [w:] Nowa kodyfikacja karna. Kodeks karny. Krótkie komentarze, z. 7, Warszawa 1998, s. 84.

29 Trafnie omawiany niedostatek regulacji art. 12 k.k. ilustruje Łukasz Pohl, podając przykład mężczyzny, który w zamiarze z góry powziętym, w krótkich odstępach czasu dopuszcza się zgwałcenia swojej małżonki. W takim przypadku niemożliwość modyfikacji granic odpowiedzialności karnej na podobieństwo skutków ciągu przestępstw razi swą niesprawiedliwością. Ł. Pohl, [w:] Kodeks karny. Komentarz, red. R.A. Stefański, Warszawa 2015, s. 191. W podobnym tonie krytyczny pogląd w kwestii pominięcia w ustawie możliwości nadzwyczajnego obostrzenia kary wobec sprawcy czynu ciągłego wyraża także Aneta Michalska-Warias. Uzasadnia je nie mniej sugestywnym przypadkiem zupełnie nieuprawnionego uprzywilejowania w traktowaniu sprawców kilkukrotnego pobicia tej samej osoby w warunkach zamiaru z góry powziętego (art. $158 \S 1$ k.k. w zw. z art. 12 k.k.) w stosunku do takiego samego pobicia kilku osób w zamiarze każdorazowo odtwarzanym, podejmowanym sukcesywnie. W pierwszym przypadku, mimo istnienia pewnej trwałości złego postanowienia wynikającej z przyjęcia „z góry powziętego zamiaru” wielokrotnej realizacji znamion czynu zabronionego, sprawcy odpowiadaliby do 3 lat kary pozbawienia wolności, w drugim natomiast, za sprawą reguły progresji karania określonej w art. $91 \S 1$ k.k. do 4 lat i 6 miesięcy. Trudno takie rozwiązanie uznać nie tylko za racjonalne, lecz także sprawiedliwe, choćby z punktu widzenia konstytucyjnej zasady równości. A. Michalska-Warias, Niektóre 
nadzwyczajnego, a nawet ustawowo zadekretowanego zwyczajnego obostrzenia kary — na podobieństwo art. 52 k.k. z 1969 roku określającego konsekwencje tak zwanej recydywy ogólnej — wywołuje zatem stan poważnej asymetrii między konsekwencjami art. 12 k.k. a następstwami zbiegu przestępstw z art. 91 § 1 k.k. Sekwencyjność (seryjność, powtarzalność) jako okoliczność, która zwiększa naganność zachowań sprawcy, charakteryzuje przecież nie tylko ciąg przestępstw, ale i czyn ciągły.

Przytoczone analogie prowadzą do wniosku, że tak znaczna dyferencjacja na poziomie wymiaru kary w przypadku obu instytucji opiera się na niezwykle niepewnej od strony dowodowej przesłance ,z góry powziętego zamiaru”. W sytuacji więc, w której sprawca dopuścił się kilku przestępstw spełniających wszystkie warunki ciągu i gdy dodatkowo ziści się warunek subiektywny wynikający z art. 12 § 1 k.k., konieczne staje się przyjęcie konstrukcji czynu ciągłego, która istotnie uprzywilejowuje sytuację sprawcy. Nie można przy tym tracić z pola widzenia tego, że przesłanka ,zamiaru z góry powziętego” musi być przyjęta nie tylko wówczas, gdy sąd na podstawie materiału dowodowego odnoszącego się do całokształtu okoliczności przedmiotowych i podmiotowych nie ma wątpliwości co do jego istnienia, ale — zgodnie z zasadą in dubio pro reo - także w tych przypadkach, w których takie wątpliwości się zrodzą, gdy jednak sprawca konsekwentnie utrzymuje, że działał ,na raty”. Kontrdowód na brak takiego zamiaru, wobec powszechnie znanych trudności towarzyszących dowodzeniu treści strony podmiotowej, może być niemożliwy do przeprowadzenia. Wątpliwości te muszą być więc ostatecznie uwzględniane na korzyść sprawcy. Trafnie w tym kontekście zauważa Łukasz Pohl, że operowanie w przypadku czynu ciągłego reakcją karną w wymiarze przewidzianym dla zachowań jednokrotnie realizujących znamiona czynu zabronionego ,jest absolutnie niesłuszne, gdyż wyraża ono niezrozumiałą dla karnisty optykę czynienia z zamiaru popełnienia wielu czynów zabronionych (składowych czynu ciągłego) ustawowej okoliczności polepszającej sytuację sprawcy", co prowadzi go ostatecznie do sformułowania postulatu uczynienia z tej okoliczności odrębnej podstawy nadzwyczajnego obostrzenia kary prowadzącej do podwyższenia górnego progu odpowiedzialności karnej o połowę ${ }^{30}$. Konstrukcja czynu ciągłego w obowiązującym ujęciu niewątpliwie taką właśnie korzystniejszą sytuację po stronie sprawcy tworzy. W tym stanie rzeczy, w rzeczywistości procesowej, kreatywna co do treści strony podmiotowej linia obrony sprawcy kilku przestępstw jest zatem nie tylko bardzo prawdopodobna, ale w razie profesjonalnej

problemy przestępstwa ciagłego i tzw. ciagu przestępstw $w$ rozumieniu art. 12 k.k. i art. 91 k.k., AUMCS Sectio G 47, 2000, s. 216.

30 Ł. Pohl, O potrzebie zmian w części ogólnej k.k. na tle węzłowych zagadnień nauki o przestępstwie (wybrane propozycje de lege ferenda), [w:] O stabilności kodeksu karnego w świetle realiów. Księga Jubileuszowa prof. zw. dra hab. Stanisława Hoca, t. 2, red. D. Mucha, Opole 2018, s. $155-156$. 
pomocy prawnej i minimum okoliczności faktycznych wskazujących na możliwość istnienia zamiaru z góry powziętego niemal pewna.

Z kolei odnosząc się do argumentacji, łączącej rezygnację z możliwości nadzwyczajnego obostrzenia kary w stosunku do czynu ciągłego z podobieństwem do kategorii ,przestępstw zbiorowych”, za które sprawca odpowiada wszakże w granicach „zwyczajnego”, a nie „,nadzwyczajnego” wymiaru kary, należy zauważyć, że ustawowa rzeczywistość przedstawia się dokładnie odwrotnie. Argumentacja tego stanowiska zdaje się nie uwzględniać ustawowego faktu, że powtarzalność (wielokrotność, ciągłość) zachowań składających się na realizację znamienia czasownikowego przestępstw wieloczynnościowych zwiększająca stopień ich społecznej szkodliwości, znajduje swoje wyraźne odzwierciedlenie w ustawowym zagrożeniu karą przewidzianą za tę kategorię przestępstw. W tym stanie rzeczy niepodobna zaakceptować pogląd odwołujący się do argumentu ,zwyczajnego wymiaru kary” za te przestępstwa, iż ustawodawca, określając granice odpowiedzialności karnej, nie różnicuje oceny zachowań pojedynczych i ich zbioru w sankcji. Zupełnie co innego wynika bowiem z porównania granic ustawowego zagrożenia przewidzianego za jednokrotne i wielokrotne naruszenie określonej normy sankcjonowanej ${ }^{31}$. Stosując więc analogiczne rozumowanie, przyjęcie możliwości nadzwyczajnego obostrzenia kary za czyn ciągły z art. 12 § 1 k.k. należałoby uznać nie tylko za rozwiązanie z tej perspektywy w pełni konsekwentne, wpisujące się w ogólniejszy obraz gradacji karalności zachowań jednokrotnych i wielokrotnych, ale i całkowicie racjonalne z punktu widzenia realizacji polityki karnej, pozwalające na możliwość surowszego potraktowania sprawcy w przypadkach, których sumaryczna ocena tego by wymagała, a co tylko w odniesieniu do nielicznych typów czynów zabronionych — operujących ilościowym znamieniem skutku — jest możliwe, gdy znajduje wyraz w surowszym zagrożeniu karą przewidzianym za typ kwalifikowany.

Wreszcie, odnosząc się do argumentu podmiotowego negującego potrzebę nadzwyczajnego wymiaru kary za przestępstwo ciągłe, za czym miałoby jakoby przemawiać usprawiedliwiające postawę sprawcy ,stępienie jego wrażliwości moralnej" wskutek wielokrotnej realizacji znamion czynu zabronionego, co w konsekwencji miałoby umniejszać jego winę, należy stwierdzić, iż w optyce tej zgadza się jedynie przyjęta wstępnie teza zakładająca ,stępienie wrażliwości” sprawcy. Jako logicznie i kryminalnopolitycznie niepoprawne ocenić należy nato-

31 Można o tym z łatwością się przekonać, porównując chociażby granice zagrożenia karą za znieważenie (art. $216 \S 1$ k.k. — kara grzywny albo ograniczenia wolności), naruszenie nietykalności cielesnej (art. 217 § 1 k.k. — kara grzywny, ograniczenia wolności albo pozbawienia wolności do roku) czy lekki uszczerbek na zdrowiu (art. 157 § 2 k.k. — kara grzywny, ograniczenia wolności albo pozbawienia wolności do lat 2), realizowane jako pojedyncze zachowania, z zagrożeniem przewidzianym za przestępstwo znęcania się (art. $207 \S 1$ k.k. — kara pozbawienia wolności od 3 miesięcy do 5 lat, a w odniesieniu do typów kwalifikowanych z $§ 2$ lub 3, odpowiednio do 10, a nawet 12 lat pozbawienia wolności), którego znamię czasownikowe realizują wszakże powtarzalne zachowania, a brane pod uwagę z osobna mogą wyczerpywać znamiona wymienionych typów przestępstw. 
miast wnioskowanie w takiej sytuacji o potrzebie łagodności ustawy. Powtarzalny brak respektu dla normy prawnej nie może być bowiem usprawiedliwiany, co ujawnia się choćby w szczególnych zasadach karalności sprawców przestępstw powrotnych czy tych, którzy uczynili sobie z ich popełniania stałe źródło dochodu. Zobojętnienie sprawcy wobec zakazu karnego, zwłaszcza gdy jego źródłem jest powtarzalność zabronionych przez ustawę zachowań, w żadnym razie nie może być traktowane jako okoliczność redukująca, a w najlepszym razie stabilizująca zakres odpowiedzialności karnej. Stępiona wrażliwość sprawcy wymaga bowiem raczej jej „wyostrzenia”, w tym przy użyciu racjonalnie surowej represji karnej, niż pobłażliwości uzasadnianej rzekomo niższym stopniem zawinienia.

\section{IV}

Podsumowując powyższe rozważania stwierdzić należy, iż ogólny kierunek zaostrzenia represji karnej przyjęty w projekcie kodeksu karnego z 1997 roku nie jest właściwy. Wyraża on niczym nieuprawnioną wiarę w omnipotencję kar surowych i bardzo surowych. W kontekście tej oceny nie można tracić z pola widzenia naukowej refleksji dotyczącej zasadności i celowości zwiększania represyjności karania. Powszechnie we współczesnej dogmatyce prawa karnego wyrażany jest wszakże pogląd, iż z perspektywy efektywnie realizowanej polityki karnej brak wyraźnego - a w radykalnym ujęciu tego stanowiska, jakiegokolwiek — związku między zaostrzaniem odpowiedzialności karnej a zmniejszaniem się liczby popełnianych przestępstw. Przyjęte w projekcie założenie pozostaje w jawnej sprzeczności nie tylko z tym poglądem doktryny prawa karnego, ale i z uniwersalną regułą kształtowania odpowiedzialności karnej wyrażoną już bez mała trzy wieki temu przez Charles'a de Montesquieu, z której wyprowadzić można ogólniejszą prawdę i zarazem diagnozę, iż przyczyna przestępczości tkwi „w bezkarności zbrodni, nie w umiarkowaniu kar”. Jak wywodzi Monteskiusz, „doświadczenie poucza, iż w krajach, w których kary są łagodne, działają one na obywateli tak samo, jak gdzie indziej wielkie"32. Zauważalny dystans projektodawcy do tej starej mądrości, zaproponowane w projekcie kodeksu karnego z 25 stycznia 2019 roku zmiany, w tym w szczególności wynikające z tak radykalnego zwiększenia represyjności karania, czyni - co do zasady — nieprzekonującymi. Wyjątkiem może tu być zmiana wynikająca $\mathrm{z}$ proponowanego wprowadzenia art. 57b, przywracającego formalnie symetrię w zakresie karania ciągu przestępstw i czynu ciągłego. Inną kwestią, na której rozwinięcie w tym opracowaniu nie ma już jednak miejsca, jest natomiast to, iż idea przywrócenia tej „,równowagi” karalności czynów popełnianych sekwencyjnie zrealizowana została z przesadnym „rozmachem”. W szcze-

32 Ch. de Montesquieu, O duchu praw, przeł. T. Boy-Żeleński, ks. VI, rozdz. XII, O potędze kar, s. 46. 
gólności zmiana ta powinna uwzględniać przywołany i podzielany przez autora tego opracowania argument zwolenników status quo, odwołujący się do zakazu podwójnego uwzględniania tej samej okoliczności w wymiarze kary. Możliwość nadzwyczajnego obostrzenia powinna być więc ograniczona do tych tylko przypadków, gdy jednostkowe zachowania tworzące przestępstwo ciągłe są odrębnymi przestępstwami, których wielość nie znajduje jednocześnie możliwości surowszego potępienia w ramach sankcji przewidzianej dla typu kwalifikowanego wyodrębnionego w oparciu o znamię ilościowe. Także rozwiązanie co do arytmetycznego przelicznika wymiaru kary nadzwyczajnie obostrzonej za czyn ciągły uznać należy, jako nazbyt represyjne, za niewłaściwe. W tym zakresie w pełni wystarczające byłoby posłużenie się analogiczną formułą progresji karania jak ta, która wynika z art. $91 \S 1$.

\title{
REMARKS ON CRIMINAL LIABILITY FOR CONTINUOUS CRIME IN VIEW OF THE DRAFT AMENDMENT TO THE PENAL CODE OF 25 JANUARY 2019
}

\author{
Summary
}

The study contains an analysis and evaluation of some legal solutions proposed in the draft amendment to criminal law of 25 January 2019, especially regarding the sentence, both statutory and judicial. Attention was paid to changes that constitute the most vivid manifestations of the tendency clearly outlined in the draft - expressed explicitly in the assumptions of the postulated changes - towards increasing the repressive norms of the Penal Code of 1997. This is carried out on three main levels - 1) increasing the severity of sanctions for individual, selected types of crimes, 2) extending the application of the extraordinary institution to tighten the penalties and 3) changes to the court directive on the sentence. The study focuses on changes concerning the foundations and rules of the extraordinary progression of punishment, in particular on the modification referring to criminal liability for an offense committed in the conditions of a continuous act covered by the formula of Article $12 \S 1$ of the Penal Code. In this case, the project provides for mandatory toughening of the penalty by raising the lower liability threshold by half, and the upper one by two. In this regard, both the arguments of the position approving such a solution and the views of the part of the criminal law doctrine which fully accepts the law adopted in the Penal Code of 1997 and which are binding in this respect are presented.

Keywords: amendment, repressiveness, punishment, toughening of penalty, continuous act, continuous crime, extraordinary penalty

\section{BIBLIOGRAFIA}

\section{AKTY PRAWNE}

Kodeks karny skarbowy z 10 września 1999 roku (Dz.U. 1999, Nr 83, poz. 930).

Konstytucja Rzeczypospolitej Polskiej z dnia 2 kwietnia 1997 roku (Dz.U. Nr 78, poz. 483 ze zm.). 
Konwencja o ochronie praw człowieka i podstawowych wolności, sporządzona w Rzymie dnia 4 listopada 1950 roku (Dz.U. z 1993 r. Nr 61, poz. 284 ze zm.).

Ustawa z dnia 12 lipca 1995 roku o zmianie Kodeksu karnego, Kodeksu karnego wykonawczego oraz podwyższeniu dolnych i górnych granic grzywien i nawiązki w prawie karnym (Dz.U. 1995, Nr 95, poz. 475).

Ustawa z dnia 4 października 2018 roku o zmianie ustawy Kodeks wykroczeń oraz niektórych innych ustaw (Dz.U. 2018, poz. 2077).

\section{LITERATURA}

Andrejew I., Polskie prawo karne w zarysie, Warszawa 1976.

Buchała K., Prawo karne materialne, Warszawa 1989.

Cieślak M., Polskie prawo karne. Zarys systemowego ujęcia, Warszawa 1994.

Daszkiewicz K., Kary za przestępstwa ciagłe i ciagi przestępstw, Prok. i Pr. 2000, nr 5.

Daszkiewicz K., Nadzwyczajne obostrzenie kary, [w:] Nowa kodyfikacja karna. Kodeks karny. Krótkie komentarze, z. 7, Warszawa 1998.

Dąbrowska-Kardas M., Kardas P., Czyn ciagły i ciag przestępstw w kodeksie karnym z 1997 r., [w:] Nowa kodyfikacja karna. Kodeks karny. Krótkie komentarze, Warszawa 1998.

Michalska-Warias A., Niektóre problemy przestępstwa ciaglego i tzw. ciagu przestępstw w rozumieniu art. 12 k.k. i art. 91 k.k., AUMCS Sectio G 47, 2000.

Montesquieu Ch. de, O duchu praw, ks. VI, rozdz. XII. O potędze kar, przeł. T. Boy-Żeleński, Warszawa 1927.

Pohl Ł., [w:] Kodeks karny. Komentarz, red. R.A. Stefański, Warszawa 2015.

Pohl Ł., O potrzebie zmian w części ogólnej k.k. na tle węzłowych zagadnień nauki o przestępstwie (wybrane propozycje de lege ferenda), [w:] O stabilności kodeksu karnego w świetle realiów. Ksiega Jubileuszowa prof. zw. dra hab. Stanisława Hoca, t. 2, red. D. Mucha, Opole 2018.

Sadowski A., Przestępstwo ciagłe, Lublin 1949.

Zalewski W., Przestępstwo ciagle de lege lata $i$ de lege ferenda, Prok. i Pr. 2003, nr 4.

\section{ORZECZNICTWO SĄDOWE}

Wyrok SN z 12 marca 1975 roku, V KR 371/74, OSNPG 1975, nr 11, poz. 117. Wyrok SN z 22 listopada 1975 roku, IV KR 215/75, OSNKW 1976, nr 2, poz. 26. Wyrok SN z 8 lipca 1977 roku, IV KR 125/77, OSNPG 1977, nr 11, poz. 100.

\section{INNE ŹRÓDŁA}

Projekt ustawy o zmianie ustawy Kodeks karny oraz niektórych innych ustaw z dnia 25 stycznia 2019 roku, https://legislacja.rcl.gov.pl.

Uzasadnienie Projektu ustawy o zmianie ustawy Kodeks karny oraz niektórych innych ustaw z dnia 25 stycznia 2019 roku, https://legislacja.rcl.gov.pl. 